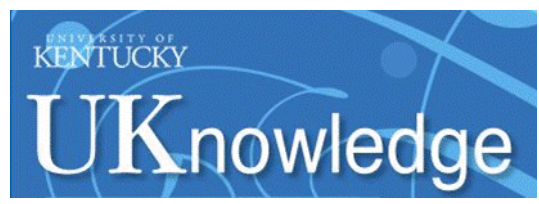

University of Kentucky

UKnowledge

\title{
You Can't Post That ... Or Can You? Legal Issues Related to College and University Students' Online Speech
}

\author{
Neal H. Hutchens \\ University of Kentucky, neal.hutchens@uky.edu
}

Follow this and additional works at: https://uknowledge.uky.edu/epe_facpub

Part of the First Amendment Commons, and the Internet Law Commons

Right click to open a feedback form in a new tab to let us know how this document benefits you.

\section{Repository Citation}

Hutchens, Neal H., "You Can't Post That . . Or Can You? Legal Issues Related to College and University Students' Online Speech" (2012). Educational Policy Studies and Evaluation Faculty Publications. 3. https://uknowledge.uky.edu/epe_facpub/3

This Article is brought to you for free and open access by the Educational Policy Studies and Evaluation at UKnowledge. It has been accepted for inclusion in Educational Policy Studies and Evaluation Faculty Publications by an authorized administrator of UKnowledge. For more information, please contact UKnowledge@lsv.uky.edu. 
You Can't Post That ... Or Can You? Legal Issues Related to College and University Students' Online Speech

Digital Object Identifier (DOI)

10.1515/jsarp-2012-6377 
Hutchens, N. (2012).

You can't post that ... or can you? Legal issues related to college and university students' online speech.

Journal of Student Affairs Research and Practice, 49(1), I-15.

doi: 10.15I5/jsarp-2012-6377

Available at http://journals.naspa.org/jsarp/vol49/issl/artl/

Innovations in Research and Scholarship Feature

\title{
You Can't Post \\ That .... Or Can You? \\ Legal Issues Related to \\ College and University \\ Students' Online Speech
}

\author{
Neal Hutchens, University of Kentucky

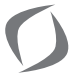

Online activities increasingly represent a common part of the student experience. Along with seeking to engage students in positive ways in relation to their online activities, colleges and universities must also deal with instances of when students' online expression potentially violates campus conduct standards. This article provides a review of legal standards relevant to students' online speech, including an examination of cases arising in an online context.

Online activities_-such as using social networking sites like Facebook and Twitter or taking academic courses wholly or partially online-now represent a common aspect of student life and the higher education experience (Kord \& Wolf-Wendel, 2009; Morris, Reese, Beck, \& Mattis, 2010). In embracing the potential benefits of students' online activity, colleges and universities also face challenges related to when online communication potentially

Neal Hutchens, Assistant Professor, Department of Educational Policy Studies and Evaluation, University of Kentucky. 
runs counter to institutional rules governing student conduct (Lipka, 2009; Mytelka, 2011; Pikalek, 2010; Seitz, 2011; Su, 2010; Wandel, 2008). Higher education institutions must balance safeguarding students' legal rights related to freedom of expression against potential harm to others, especially fellow students, caused by harmful online activity, such as bullying or harassment.

This article addresses key legal issues raised by students' online activities, particularly in the context of permissible institutional authority to regulate student speech. Along with offering a basic overview of general legal standards relevant to student speech issues at public and private institutions, this article provides a legal analysis of court decisions involving student online expression. A review of these legal standards and cases can potentially assist student affairs professionals in better understanding this emerging area of law as well as help them to ensure that institutions adhere to applicable legal requirements. Practice and policy issues raised by the review of cases are also discussed.

\section{A Brief Overview of Legal Standards Related to Student Speech}

Part of examining issues related to students' online speech entails contextualizing such speech within the overall legal standards governing student expression. As with other issues dealing with the legal relationship between colleges and universities and their students, an important legal distinction often arises on the basis of whether a student attends a public or private institution. At public colleges and universities, institutions must adhere to First Amendment requirements and satisfy due process standards. For public and private colleges and universities, contractually based standards also often create important legal obligations placed on students and institutions in relation to student speech issues. Other legal sources, such as state constitutional provisions, may provide additional legal standards relevant to student speech rights. This section first considers issues specific to public institutions in relation to First Amendment concerns and then turns to other legal obligations, especially those contractual in nature, that apply to public and private colleges and universities.

\section{The First Amendment and Public Colleges and Universities}

U.S. Supreme Court decisions clearly establish that constitutional speech protections extend to students in public higher education (Kaplin \& Lee, 2006). Cases also reveal that courts generally have granted greater discretion for colleges and universities to regulate speech within a formal instructional context than in other settings. In contrast, student speech taking place in a noninstructional setting often merits considerable First Amendment protection. If not aimed at harassing or threatening particular individuals, even distasteful or offensive student speech outside of an instructional context generally receives strong First Amendment protection (Chemerinsky, 2009; Kaplin \& Lee, 2006). 
Illustrative of the broad student speech protections often available in noninstructional settings, courts consistently have limited the reach of institutional authority over student speech taking place in campus forums created for students to express their views and ideas (e.g., Board of Regents of University of Wisconsin System v. Southworth, 2000; Healyv. James, 1972; Rosenbergerv. Rector and Visitors of University of Virginia, 1995; Widmarv. Vincent, 1981). Although institutions are permitted to require students and student groups to adhere to reasonable, content-neutral rules regulating the time, place, and manner of speech in such forums, they are not allowed to silence students on the basis of expressing views disfavored by campus officials.

Unlike the broad First Amendment speech rights often possessed by students in a noninstructional situation, courts generally have recognized enhanced institutional authority in more formal instructional settings. Supreme Court decisions have resulted in considerable legal discretion for colleges and universities when making academic decisions, which limits students' speech rights in instructional contexts (e.g., Board of Curators of University of Missouri v. Horowitz, 1978; Regents of University of Michigan v. Ewing, 1985). The Supreme Court's decision in Hazelwood School District v. Kuhlmeier (1988) has proven important in framing the contours of institutional authority over student speech in instructional settings. The case centered on secondary students, but multiple courts have applied the decision's standards to cases involving higher education students. In the case, the court determined that educators are permitted to impose reasonable regulations on students' curricular-related speech as long as they are doing so for legitimate pedagogical reasons.

\section{Other Legal Standards and Students' Speech Rights}

Although generally unwilling to reduce the student and institutional relationship to one merely contractual in nature, courts frequently turn to contract principles as an important legal source in determining the obligations existing between public and private colleges and universities and their students (Kaplin \& Lee, 2006; Sarabyn, 2010). Contractual standards are potentially more relevant at private institutions in determining the standards a college or university must adhere to in relation to restrictions placed on student speech. Private institutions generally possess considerable authority to determine the extent of any student speech rights, but arbitrary enforcement or the post hoc adoption of restrictions on a student's speech can result in an enforceable contractual violation based on standards contained in the student handbook, or other pertinent institutional policies, defining the rights and responsibilities of students (Kaplin \& Lee, 2006). Some private institutions, for example, offer protections for student speech that parallel those provided under the First Amendment to students at public institutions. At either a public or private institution, a student challenging a disciplinary action might argue that the college or university breached its contractual obligations to the student by failing to follow applicable policies and procedures.

Besides contractual standards, state constitutional provisions, statutes, and court decisions are other possible sources of student speech rights at public and private institutions (Kaplin 
$\&$ Lee, 2006). Several state constitutions, for instance, provide for speech rights potentially more expansive than those provided under the First Amendment. Some state courts have imposed a duty on private colleges and universities to provide students with a level of procedural safeguards in the student disciplinary process that resemble the due process protections placed on public institutions through the Fourteenth Amendment. State laws provide another potential source of legal protection for student speech. In one of the most notable examples, California, under what is commonly referred to as the Leonard Law, requires private institutions with a nonsectarian mission to provide students the same First Amendment speech protections as would exist at a public college or university (Ross, 2007). Although subject to certain limitations, private colleges and universities generally possess more legal leeway in the regulation of student speech than do public institutions. Along with noting the significance of the public and private distinction with regard to student speech rights, it is important to recognize that legal standards besides those grounded in contract or the First Amendment can help to shape the permissible legal parameters of institutional oversight.

\section{Illustrative Legal Decisions Specific to Students' Online Expression}

Building on the overview of legal standards generally governing student speech rights, we now consider selected legal decisions specifically involving students' online speech. Cases were located using the Westlaw legal database through (a) a terms and connectors search using such words and phrases as "students" and "online" and "First Amendment" and "speech" and (b) an examination of the citation history of cases located through the terms and connectors search. Recognizing the important legal distinctions often made by courts regarding the context in which student speech takes place, this section first discusses cases involving an instructional dimension, including practicums and internships, and then turns to decisions taking place outside of formal instructional settings.

\section{Online Speech Cases with a Formal Instructional Dimension \\ Cases involving course discussions and communications. Concerning} curricular-related speech taking place in an online context, courts typically have adhered to the general legal standards recognizing substantial institutional authority to regulate student speech in instructional matters. In one decision that has emerged involving online speech, a student at a public university challenged disciplinary action taken against him for online postings deemed disrespectful toward other students in a class taught in a largely online format (Harrell v. Southern Oregon University, 2009). The university's student conduct standards contained a provision that dealt with disrupting educational activities and discussed engaging in communication that distracted or demonstrated disrespect toward others in the class. According to university officials, the student made comments that included critical assessments of classmates asserting that they had 
not bothered to read the other student postings or assigned class materials before making posts on an online comment board. In reviewing the student's claims, the court turned to the standards announced in Hazelwood (1988), stating that the institution could regulate student speech that created a legitimate and substantial disruption to the educational process.

In challenging the actions taken against him, the student relied on previous decisions in which courts struck down general antiharassment policies adopted by colleges or universities that covered activity in and out of the classroom. In those cases, courts had determined that the policies in question were overly broad (i.e., restricted speech that was actually protected by the First Amendment) or vague (i.e., the standards made it difficult for students to determine exactly what types of speech would be impermissible). The court in Harrell rejected these arguments, determining that the institution's policy targeted speech in a narrower way than did the cases on which the student relied. According to the court, referencing disrespect in connection with the disruption of educational activities in the relevant institutional policy provided sufficient notice to students concerning what types of conduct and speech on their part might violate permissible standards of class conduct.

In addition to rejecting arguments that institutional rules related to class speech should fail because of vagueness or overbreadth considerations, the court determined that the university could discipline the student on the basis of his actual comments. The opinion stated that the Supreme Court had recognized considerable institutional discretion to regulate speech in the context of the class environment. In addition, the court pointed out that the student could easily have expressed his views without resorting to insulting other students. According to the court, the university's interest in creating a classroom environment conducive to student learning permitted it to discipline the student based on the insulting nature of his online comments.

In another case dealing with an online course at a public college, Feine v. Parkland College ([Feine $], 2010$ ), the court reached a similar decision and, in fact, looked to the Harrell (2009) decision for support. The student in Feine made online comments regarding another student that the instructor deemed inappropriate, and the instructor warned the student in question, Feine, to modify his future online postings directed at other students in the course. Feine continued to make questionable postings, and the student who was the target of his online comments eventually initiated a harassment complaint against him. This series of events resulted in the initiation of disciplinary action against Feine. In reviewing the matter, the court determined that the institution did not discipline the student for the content of his speech but, rather, for the student's "manner of writing and his personal attacks on the postings of another student" (p. 6). As such, the court determined that the student could not rely on the First Amendment for protection. The opinion stated that even if the student could establish that his actions qualified as expression deserving some degree of First Amendment protection, online class discussions did not constitute a type of open student forum. Instead, the class environment, including its virtual aspects, represented a nonpublic forum. This meant that the college, in furtherance of legitimate pedagogical 
aims, could impose reasonable restrictions on the manner in which students communicated their views.

One of the earlier cases involving online speech issues, Rollins v. Cardinal Stritch University ([Rollins], 2001), resulted in a similar outcome as the Feine (2010) and Harrell (2009) decisions. In Rollins, a student at a private university was removed from a student cohort because of harassing e-mails that he sent to fellow students. For instance, the student sent an e-mail to a female student with an image of "kissing lips" and a message appearing with the e-mail stating that it was for the man or woman in one's life (p. 466). He also sent the same student an additional message concerning a student at another institu tion who had successfully avoided criminal liability for an Internet posting involving the fantasy kidnapping, torture, and murder of a female classmate. Though advised to refrain from engaging in offensive conduct in class or by e-mail, the student continued to send e-mails that upset other students.

After his removal from the cohort, the student challenged the disciplinary action taken against him by the university. In assessing the student's claims, the court discussed decisions in several states that had imposed a legal duty on private institutions in the disciplining of students similar to that placed on public institutions based on the due process clause of the Fourteenth Amendment. This duty meant that a private college or university could not arbitrarily expel a student. According to the court, the university satisfied legal requirements in providing sufficient notice to the student and basing its action against him on legitimate institutional efforts to maintain a positive and welcoming educational environment. The court pointed out that the student handbook informed students that the institution had the authority "to preserve for all its students an environment that is conducive to academic pursuit, social growth and individual discipline" (Rollins, 2001, p. 471). Such language, according to the opinion, put the student on notice that the university reserved the right to regulate class exchanges.

Although an extensive body of case law does not yet exist, emerging case law such as that discussed in this section suggests that colleges and universities, including public ones, possess substantial authority to regulate students' course-related online speech. Judicial recognition of institutional authority in this area comports with the general legal standards approved by courts in regard to student speech issues arising in the physical classroom.

Preprofessional placements: Practicums and internships. Courts also have considered the legal standards that should apply in relation to online speech occurring outside of the immediate class environment (whether virtual or physical) that involve students undertaking internships or practicums as part of fulfilling their academic requirements. One of the cases, Yoder v. University of Louisville ([Yoder], 2009), demonstrates the potential importance of contractual standards at public colleges and universities as well as the need to provide clear notice to students regarding expected professional standards. Yoder (2009) involved a student who was dismissed from a nursing program at a public university based on postings appearing on her personal page on the 
social networking site MySpace. In her postings, the student made comments about an obstetric patient she observed during the birthing process as part of the student fulfilling the requirements of a nursing course. The student made online comments that included "Beautiful pregnant women are beautiful, or more like, only slightly distorted with the belly... Otherwise, pregnancy makes an ok-looking woman ugly, and an ugly woman-fucking horrifying" (p. 4). In addition, the student referred to the infant by the term "Creep" (p. 6).

The course's instructor, upon learning of the online content, believed that the student violated the school of nursing's honor code, the course's confidentiality agreement, the terms of the consent agreed to by the mother, and the general standards of the nursing profession. The instructor brought the blog comments to the attention of administrators, and the student was eventually dismissed from the nursing program.

In a lawsuit challenging the dismissal, the student claimed that the university violated her constitutional rights. The trial court in Yoder (2009) ruled in favor of the student, though on contractual grounds instead of First Amendment ones, stating that the nursing school's policies failed to put the student on notice that her online postings could violate professionalism standards. In reviewing the decision, the U.S. Court of Appeals for the Sixth Circuit (Yoderv. University of Louisville, 2011) held that the student had not raised the contractual issue for the lower court to consider, and the case was sent back to the trial court for further consideration.

Even though the initial ruling in favor of the student was not sustained on procedural grounds, the original trial court opinion in Yoder (2009) has potential lessons for colleges and universities in relation to students' online speech issues. According to the trial court's opinion, the applicable standards governing the student's conduct and speech activities referred to the disclosure of identifying information, but the court determined that the information posted by the student did not constitute such information. It stated that if the school of nursing meant to include the type of information contained in the posting then it bore a responsibility to provide "fair notice" to the student (Yoder, 2009, p. 16). The opinion discussed that the professionalism standards relied on by the university failed to define the kind of conduct and information discussed by the student in her online postings as contrary to the school's standards. The court also found it relevant that the student did not seek to hold herself out as a representative of the institution.

An important lesson from the Yoder (2009) case is that institutions need to make sure that they put students on notice regarding the kinds of online speech that might violate student conduct or preprofessional standards. The importance of such notice may be seen in a case with somewhat similar characteristics, Snyderv. Millersville University ([Snyder], 2008). The decision involved the removal of a public university student from a student teaching placement, which prevented her from obtaining teacher certification. As part of her student teaching experience, the student was provided a guide informing her that she was expected to adhere to the same professional standards as full-time teachers at the placement school. Student teaching placement coordinators for 
the university warned students not to refer to students or teachers on personal webpages or to "friend" students and relayed a previous story concerning a student who had suffered dismissal from a practicum for such activity.

The student ignored this advice and discussed her MySpace page with students at the placement school. In one incident, the student teacher confronted a student at her placement school who had recognized and communicated with a friend of the student teacher as a result of viewing content observed through the student teacher's MySpace page. The student teacher discussed the incident involving the student on her MySpace page. In this same posting, the student teacher appeared to refer to a school official as the reason for not wanting to apply for a permanent position at the school. Additionally, the court discussed pictures of the student teacher on her page that showed her with a caption entitled "drunken pirate" (p. 6). Officials at the placement school, based on the MySpace postings and other problems related to professionalism and competency, dismissed the student from her placement. This decision meant that the university could not award the student an education degree because of state requirements, and the university offered to permit the student to graduate with a degree in English instead.

In its analysis, the court determined that a threshold issue involved whether the student should be viewed as a student or as an employee for purposes of her First Amendment claims. Influenced by the fact that the student did not attend any classes at the university during the period of the placement and the professional nature of the duties required of the placement, the court determined that she occupied a role closer to a public school teacher rather than a university student. This meant the student's speech claims were subject to evaluation under First Amendment standards governing public employees. Under these standards, eligibility for First Amendment protection for the speech in question hinged on whether the student teacher was speaking as a private citizen on a matter of public concern. According to the opinion, the speech at issue did not raise issues of public concern so the student could not make a First Amendment argument regarding the MySpace postings. The court decided that the student should not receive the same kinds of First Amendment protections that often attach to student speech. Instead, the court analyzed the student's speech claims under the more restrictive standards applied to speech claims by public employees.

In this evolving area of law, the Snyder (2008) and Yoder (2009) cases provide some interesting contrasts. The lower court in Yoder (2009) did not consider whether any other legal standards should apply besides those generally used to analyze student speech claims. The student in Yoder $(2009,2011)$ was not in the same kind of full-time placement as was the student teacher in Snyder, but the cases reveal courts grappling with how existing legal standards should apply to students' online speech. The decisions demonstrate the need for colleges and universities to make clear any heightened professional expectations placed on students' online activities in relation to fulfilling practicum and internship requirements. 


\section{Online Speech Occurring Outside of a Formal Instructional Context}

Institutional authority often diminishes in relation to student speech taking place outside of a formal instructional setting, especially for public colleges and universities. The case Murakowski v. University of Delaware ([Murakowski], 2008) shows the extensive speech rights potentially available to students in such contexts at public institutions. In this decision, the court held that a university could not discipline a student for postings made on his personal website discussing violence and sexual abuse, even though the website was maintained on a web server operated by the university.

The university had a responsible use policy that directed students to "abide by all local, state and federal laws that pertain to communications and to publishing" (Murakowski, 2008, p. 575). The policy advised students not to consider Internet postings as private or even confined to members of the campus community, but it stated that the university intended to impose no other limitations on content than those required by applicable law. In one posting, the student provided specific instructions and alleged pictures of the various steps involved in skinning a cat. In another he proposed, as a response to Sexual Assault Awareness Day, to "obtain a sexual awareness t-shirt and 'wear it while I'm raping some drunk girl in a dark alley"' (Murakowski, 2008, p. 577). In additional postings the student discussed other ways to engage in violence and sexual assault against women.

The institution charged the student with violating its computer use policy. In the ensuing litigation, the court held that the university failed to demonstrate that the student's "writings caused a material disruption or was likely to do so" (Murakowski, 2008, p. 592). The opinion stated that, although disturbing and offensive, the student's online postings did not reveal any intent to actually inflict harm and were not directed at specific individuals. The court did determine that the university acted appropriately in its actions taken against the student in relation to his ignoring an order not to return to his residence hall during the institution's investigation of his postings. The court's response to these actions by the institution indicate that a college or university is allowed to take immediate action in determining whether a student's online speech constitutes a credible danger to members of the campus community. Although not all courts might have decided that the speech at issue in Murakowski merited First Amendment protection, the case is instructive of how students' speech at public colleges and universities, including online speech, often receives considerable First Amendment protection, especially when made outside of an instructional environment.

A case involving a student at a public university in Georgia, Barnesv. Zaccari ([Barnes], 2010), further illustrates how institutional responses to students' online speech must comport with constitutional due process requirements and First Amendment standards. In Barnes, a student attracted the university president's anger through actions that included Facebook postings by the student that were critical of a parking garage being constructed by the university. Eventually, and against the advice of the institu tion's legal counsel, the president opted to administratively remove the student. Although dismissing various claims raised by the student against other university officials, the court determined that the president acted in a unilateral fashion in denying the student 
an opportunity to receive a prewithdrawal notice of the allegations against him and in denying him the opportunity for some kind of hearing before an impartial decision maker. Although not directly addressing the First Amendment issues potentially at stake in the case, the decision reinforces the need for institutions to satisfy due process standards and to follow established policies and procedures in responding to online speech incidents. Along with identifying apparent constitutional deficiencies, the court refused to dismiss a breach of contract claim alleging that the university failed to follow its own policies and procedures in its treatment of the student.

Even as cases involving online student speech outside of instructional settings continue to emerge and provide guidance for institutions, decisions such as Murakowski (2008) and Barnes (2010) demonstrate the general principle that institutional authority over student speech often diminishes outside of formal instructional settings, especially for public colleges and universities. Although private colleges and universities may choose to exercise more control over their students' speech, they still must abide by established institutional policies and procedures or run the risk of potential legal liability on the basis of failing to fulfill their contractual obligations to students. Although online expression may garner heightened unwanted attention on and beyond campus in comparison to other forms of student speech, a college or university, whether public or private, must honor its legal responsibilities to students. This often means, especially in the case of public institutions, that students possess substantial rights for online speech made outside of a formal instructional setting.

\section{Policy and Practice Considerations}

Along with hopefully imparting the reader with a sharper understanding of the legal standards applicable to online student speech, a review of emerging case law in this area provides several policy and practice insights. As a guiding principle, the cases reinforce the fact that online activity often involves speech, and colleges and universities, both private and public, must respect accompanying legal protections for student expression. In responding to problems that arise with students' online activity, institutions must not abridge students' legally protected speech rights.

\section{Importance of Shifting Contexts and Student Roles in Regulation of Online Speech}

The cases reviewed reveal how some students struggle in distinguishing the different contexts in which online speech takes place and how the various roles carried out by students result in different kinds of legal protections and obligations depending on the specific situation. Decisions such as Harrell (2009) and Feine (2010) illustrate that certain students may falsely assume that the broad First Amendment protections generally available to citizens (including students) exist in instructional contexts with an online facet. That is, some students may fail to grasp, for instance, that making an online comment for a course in a residence hall or in an off-campus apartment is not legally equivalent to student speech often taking place in such locations and generally 
afforded substantial legal protection. Instead, such online communication is more legally analogous to speech made as part of a class session in a physical classroom.

A case such as Snyder (2008) illustrates the difficulty some students encounter in discerning relevant legal distinctions in what constitutes public and private information and when institutions are permitted to take action against students based on their online activity. The decision echoes the findings of research on students' social networking activities and the difficulties they may encounter in navigating privacy issues (Timm \& Duven, 2008). In Snyder, the court evaluated the student's online speech under the professional and legal obligations placed on practicing teachers, resulting in much less expansive speech rights than those relied on in a case like Murakowski (2008). The Snyder case reinforced the importance of colleges and universities helping students to understand that professionally-based conduct and ethical standards can subject students' online speech to heightened institutional regulation, even when the student assumes the speech to be "private."

Snyder (2008), along with Yoder (2009), suggests that student confusion could especially arise in relation to practicums or internships, where students could run into difficulties in navigating between their roles as preprofessionals versus their roles as students and in distinguishing between what actually constitutes publically available speech not protected by any type of legal privacy standards. Students could assume incorrectly, for example, that content on their social networking pages from sites such as Facebook are somehow immune from scrutiny by university officials on privacy grounds or are subject to expansive legal speech protections otherwise generally available to students and other citizens under the First Amendment.

In addressing students' online activities, such as in orientation sessions and study skills courses, the cases indicate the importance of emphasizing how context and role (e.g., acting in a preprofessional capacity) may likely have more legal significance than the physical place where a student engages in online activity. The decisions highlight the importance of helping students to avoid relying on false assumptions concerning their "private" online speech and available legal protections related to privacy that would provide them immunity from institutional scrutiny. Along with providing specific examples that help to explain the importance of role and context in relation to institutional authority to regulate students' online speech, students might benefit from interactive activities where they are able to "wear" (perhaps literally) different kinds of online "speech hats" that are subject to varying degrees of institutional regulation. Such activities could assist students in better understanding the important nuances that accompany their online speech in relation to the resulting level of institutional authority.

\section{Shaping Institutional Responses and Policies Related to Students' Online Speech}

Even as institutions help students act responsibly in relation to their online activities, colleges and universities must make determinations regarding the appropriate institutional 
practices and procedures to put in place, including such decisions as enactment of a formal student social media policy. In considering the creation of such policies, colleges and universities should assess whether existing institutional rules already address the types of problematic online speech at issue, as well as the benefits of creating a separate policy. Additional policies, if adopted, need to conform to pertinent legal standards protecting student speech (Burl, 2011). In considering policies and procedures, whether existing or new, the Yoder (2009) decision highlights that colleges and universities should place students on appropriate notice as to when their online activity could violate institutional standards. In adopting a policy or amending existing standards, institutions should draft language broadly enough to permit for the emergence of new technologies (Burl, 2011).

In shaping institutional responses to students' online speech issues, a key subject deals with questions over any kind of formal or informal monitoring of online content or the appropriate response by officials when confronted with questionable content (Burl, 2011; Stripling, 2011). Although accessing online content generally available to the public may not raise privacy concerns in a legal sense, colleges and universities should consider carefully the extent to which systematic monitoring of students' online activities comports with institutional values along with the feasibility of such efforts, which would likely prove unwieldy at many institutions. Given the challenges presented by any type of systematic monitoring, some legal commentators have raised concerns that ad hoc monitoring or inconsistent enforcement practices could be viewed by courts as arbitrary enforcement of student conduct standards (Van Der Werf, 2007).

Although this article suggests that institutions should tread cautiously in relation to any kind of systematic monitoring of students' online activity, college and university officials can and should respond to questionable online speech that comes to their attention. For example, in the Murakowski (2008) case, administrators became aware of the student's online postings following a complaint filed with the university police department. Although the court determined that the student's speech in that case received First Amendment protection not punishable under the university's computer use policy, it did not find fault with the university for launching an investigation and removing the student from his residence hall to make sure that the student posed no credible threat to other students. In fact, failure of an institution to respond adequately to the kinds of concerns or complaints raised in Murakowski (2008) could subject a college or university to possible legal liability. Besides potential tort concerns, bullying, harassing, or threatening online speech could result in legal liability for institutions under civil rights laws such as Title IX (Burl, 2011). This kind of possibility was present in cases like Feine (2010), Harrell (2009), and Rollins (2001), in which students initiated formal complaints because of harassing online speech. If the institutions had failed to properly address those concerns, they could have faced potential liability under state or federal civil rights standards.

In responding to online speech issues, colleges and universities should recognize that, even if a student's online speech does not violate student conduct rules or other legal standards, this does not leave an institution without recourse. When faced with student speech deemed 
hurtful and disrespectful, but nevertheless legally protected, a college or university should respond by disavowing the objectionable expression. Besides reaching out to students who engage in questionable online expression for voluntary counseling and intervention, a college or university can provide support services to individuals on campus subjected to the negative effects of such speech.

\section{Addressing Issues Beyond Institutional Regulation and Authority}

Although this article focused on legal decisions dealing with institutional regulation of students' online speech, colleges and universities should engage students more broadly and deeply regarding issues related to their online expression. Student affairs professionals should integrate consideration of institutional standards related to online expression within larger efforts to help students avoid making negative choices in relation to their online activity. For instance, online speech representing a credible threat against specific individuals or institutions could subject a student to civil or criminal liability. Some students might be surprised to learn that employers increasingly conduct searches for online content related to job candidates (Kolek $\&$ Saunders, 2008). College and university educational efforts related to students' online activity also provide an opportunity to help students more fully comprehend the potentially negative effects their online expression can have on others. Accordingly, as part of assisting students in better understanding the parameters of institutional authority over their online expression, colleges and universities have a more general opportunity to help students reflect on a range of issues related to their online activity.

\section{Conclusion}

A review of legal decisions involving students' online speech helps provide guidance to colleges and universities in navigating this emerging area of law. The cases suggest that, alongside the need for clear institutional standards, colleges and universities should help students to understand the different kinds of online "speech hats" they wear. Some students, for instance, may fail to recognize that enhanced institutional authority over student speech in instructional settings applies to online activity, even when a student engages in class-related online expression in a seemingly "private" setting such as a residence hall room. Similarly, although the cases reveal a degree of legal uncertainty, student affairs professionals can help students recognize the potential applicability of professionalism standards to their online speech in relation to preprofessional placements such as practicums and internships.

In responding to questions and challenges presented by students' online expression, colleges and universities should not shy away from their general commitment to fostering student growth. Engagement with students regarding online speech issues provides an avenue to help students consider the overall positive and negative implications of their online activities. Rather than assuming a reactive position, colleges and universities should take a proactive stance in relation 
to students' online activity, one that ensures that institutions respect students' speech rights and also enhances student learning and development.

\section{References}

Barnesv. Zaccari, 757 F. Supp. 2d 1313 (N.D. Ga. 2010).

Board of Curators of University of Missouriv. Horowitz, 435 U.S. 78 (1978).

Board of Regents of University of Wisconsin Systemv. Southworth, 529 U.S. 217 (2000).

Burl, D. M. (2011). From Tinker to Twitter: Managing student speech on social media. NACUA Notes, 9(7). Retrieved from http://counsel.cua.edu/studlife/publications/nacuanotesmarchı6.cfm

Chemerinsky, E. (2009). Unpleasant speech on campus, even hate speech, is a First Amendment issue. William \& Mary Bill of Rights Journal, $17(3), 765-772$.

Feinev. Parkland College, 2010 WL 1524201 (C.D. Ill. 2010).

Harrellv. Southern Oregon University, 2009 WL 3562732 (D. Or. 2009).

Hazelwood School Districtv. Kuhlmeier, 484 U.S. 260 (1988).

Healyv. James, 408 U.S. 169 (1972).

Kaplin, W. A., \& Lee, B. A. (2006). The law of higher education: A comprehensive guide to legal implications of administrative decision making (4th ed.). San Francisco, CA: Jossey-Bass.

Kolek, E. A., \& Saunders, D. (2008). Online disclosure: An empirical examination of undergraduate Facebook profiles. NASPA Journal, 45(1), 1-25.

Kord, J., \& Wolf-Wendel, L. (2009). The relationship between online social networking and academic and social integration. College Student Affairs Journal, 28(1), 103-123.

Lipka, S. (2009, May 1). Colleges using technology to recruit students try to hang on to the conversation. The Chronicle of Higher Education. Retrieved from http://chronicle.com/article/Colleges-Using-Technology-to/117193/

Morris, J., Reese, J., Beck, R., \& Mattis, C. (2010). Facebook usage as a predictor of retention at a private 4-year institution. Journal of College Student Retention, 11(3), 311-322.

Murakowskiv. University of Delaware, 575 F. Supp. 2d 571 (D. Del. 2008).

Mytelka, A. (2011, March 19). Student who posted anti-Asian video rant withdraws from UCLA. The Chronicle of Higher Education. Retrieved from 
http://chronicle.com/blogs/wiredcampus/quickwire-student-who-posted-anti-asianvideo-rant-withdraws-from-ucla/30480

Pikalek, A. J. (2010). Navigating the social media learning curve. Continuing Higher Education Review, $74,150-160$.

Regents of the University of Michiganv. Ewing, 474 U.S. 214 (1985).

Rollins v. Cardinal Stritch University, 626 N.W.2d 464 (Minn. App. 2001).

Rosenbergerv. Rector and Visitors of University of Virginia, 515 U.S. 819 (1995).

Ross, J. (2007). Comment: Keeping free speech in the college marketplace of ideas: California legislation as an imperfect solution to censorship by university administrators. University of San Francisco Law Review, 41 (4), 727-762.

Sarabyn, K. (2010). Free speech at private universities. Journal of Law and Education, 39 (2), 145-182.

Seitz, A. (2011, February 7). Miami lacks social media policy. Miami Student. Retrieved from http://www.miamistudent.net/news/miami-lacks-social-media-policy-1.1966659

Snyderv. Millersville University, 2008 WL 5093140 (E.D. Pa. 2008).

Stripling, J. (2011, February 7). Panelists debate how far colleges should go to monitor online behavior. Chronicle of Higher Education. Retrieved from http://chronicle.com/article/Panelists-Debate-How-Far/126298/

Su, E. Y. (2010, February 17). Outrage over UCSD party mocking black culture. San Diego Union-Tribune. Retrieved from http://www.signonsandiego.com/news/2010/feb/17/outrage-expressed-over-party/

Timm, D. M., \& Duven, C. J. (2008, Winter). Privacy and social networking sites. In R. Junco \& D. M. Timm (Ed.): Using emerging technologies to enhance student engagement, New Directions for Student Services, No. 124 (pp. 89-102). San Francisco, CA: Jossey-Bass. doi: 10.1002/ss.297

Van Der Werf, M. (2007, March 2). Beware of using social-networking sites to monitor students, lawyers say. The Chronicle of Higher Education. Retrieved from http://chronicle.com/article/Beware-of-Using/28063/

Wandel, T. L. (2008). Colleges and universities want to be your friend: Communicating via online social networking. Planning for Higher Education, 37(1), 35-48.

Widmarv. Vincent, 454 U.S. 263 (1981).

Yoderv. University of Louisville, 2009 WL 2406235 (W.D. Ky. 2009).

Yoderv. University of Louisville, 417 F. App'x 529 (6th Cir. 2011). 